\title{
10 Radical innovations, social revolution, and the baroque guitar
}

\author{
CRAIGH.RUSSELL
}

Guitar chords with a flurry of strummed strings - sonorities we now regard as commonplace - revolutionized the sound of music at the end of the 1500 s and opened up a new universe of musical thought in Western culture. Melody and counterpoint had reigned supreme throughout the Renaissance as the principal musical aspects of a composition, but around 1600 their role was challenged by a startling new concept - harmony. Whereas previously music consisted of horizontal melodic threads interwoven into a lush polyphonic fabric (in which harmonies arose merely as an incidental byproduct), a new school of thought in the seventeenth century held that a work could be governed from the outset by its harmony. Chords were the starting point of a composition, not an afterthought. The vertical alignment of sounds, as opposed to the horizontal, became paramount. No instrument better represents this radical transformation than the guitar, which was at the forefront of this aesthetic revolution from the horizontal to the vertical. This shift is born out in the guitar's early notational systems, performance techniques, musical repertoire, and functional roles in society.

Equally importantly, the guitar found itself in the center of the social turmoil and upheavals of the seventeenth and eighteenth centuries. In the 1500 s, the guitar was a lowbrow instrument that was overshadowed by the more sophisticated vihuela and lute. But in the 1600 s, the guitar was elevated from the culture of the street to that of the royal courts. No longer confined to such venues as neighborhood barber shops or gypsy camp fires, the guitar now found itself equally at home on the operatic stage or in the hands of kings and queens. In the 1700s, traditional European class systems were turned topsy-turvy by scientific advances, a transformed economy based on industrial technologies as opposed to agricultural production, a burgeoning middle class, and world explorations that opened the door for the ensuing interactions of continents and cultures. Once again, the mercurial guitaralways adapting to new situations - found itself at the center of this newly transformed society with its middle-class values and multifarious ethnic identities.

Nothing better illustrates the shift from the horizontal perspective to the vertical around 1600 than guitar notation and guitar treatises. The first 
publication dedicated to the five-course guitar, Joan Carles Amat's Guitarra española $y$ vandola (1586), underscores the dominance of harmony over melody, since his treatise delves into the chord fingerings and harmonic progressions - the plucking of individual notes is never an issue. ${ }^{1}$ Amat compares the harmonies of a piece to the colors of a painting and then makes the bold claim that anyone can play along on any piece if he or she understands the harmonic structure:

The good and expert painter has ready at his disposal all of the colors that are necessary for painting; they are available at his whim and fancy if he wants to paint a man, or a lion, or an ox. In the same way, we have equipped ourselves with all of the chord fingerings, that are like raw material and like the painter's colors, from which one can form every kind of tonality and key by leaping from one [chord] to the next. With these fingerings one can play the vacas, gallardas, villanos, italianas, pavanas - and other similar ones - in all twelve keys. And that which makes one marvel (and to many will seem impossible!), is that with these chord fingerings, anybody at all can play along with any musical instrument on whatever piece one might play or might be able to play. ${ }^{2}$

The notation itself, too, highlights harmonic thinking. Amat indicates full chords with a single numeral. His number "l" results in E major, his " 2 " is A major, " 3 " is D major, and he continues in this manner through the circle of fifths until he ultimately reaches number " 12 " which completes the cycle on B major. He accommodates minor chords by adding the suffix "b" for bemolado (meaning "flat") to the numerals, and similarly wanders through all twelve minor harmonies; " $1 \mathrm{~b}$ " is $\mathrm{E}$ minor, " $2 \mathrm{~b}$ " is A minor, " $3 \mathrm{~b}$ " is D minor, etc. Thus, Amat's orthography splendidly clarifies each chord, but this notation leaves melody to fend for itself. In one stroke, Amat completely reverses the priorities of lute and vihuela tablature notation of the 1500 s in which melodic points are depicted with precision, but harmonies occur only as the incidental byproduct of the melodic voice leading.

After Amat's treatise, the Italians dreamed up yet another notational system called the alfabeto in which alphabet letters - rather than numeralsindicate to the guitarist which chord fingerings should be depressed. Although alfabeto fingerings are handy shortcuts that tell the guitarist particular chord shapes, unfortunately these alphabet letters do not correspond to the names of the chords in a traditional music theory sense. That is, the alfabeto chord shape designated as "A" does not produce an A major harmony but instead results in a $G$ chord. The ensuing match-ups are equally confusing and counterintuitive. The alfabeto shape designated as " $\mathrm{B}$ " produces a $C$ major harmony, the letter " $C$ " results in a $D$ major, the letter " $D$ " produces an A minor... and the system winds its way forward in a semi-arbitrary fashion. Its problems aside, alphabet tablature does provide sufficient information to get a novice strumming along with the rest of the 
Example 10.1 Millioni and Monte, Vero e facil modo d'imparare (1678), p. 6, "Alfabeto straodinario nuovamente inventato"

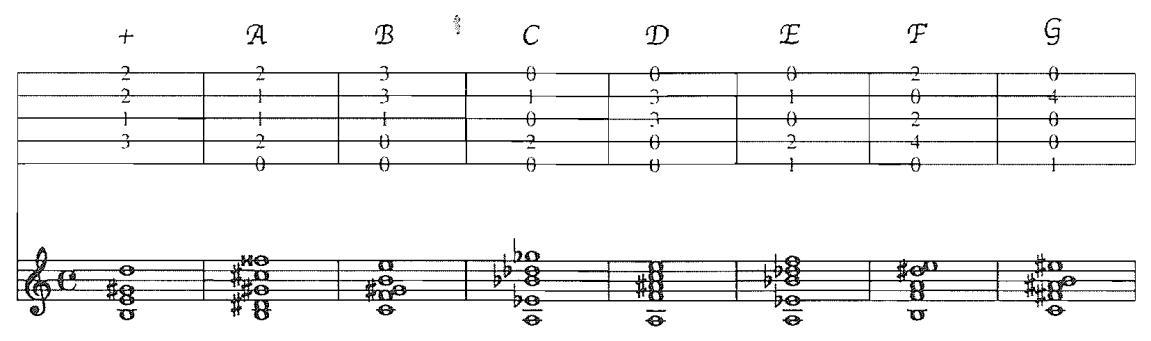

crew. And like Amat's notation, this is harmonically driven. It is the chords, not the tune, that the guitarist is playing.

The first appearance of the Italian alfabeto occurs in Montesardo's Nuova inventione d'intavolatura of $1606 .^{3}$ Montesardo's chord shapes are explicit, but his rhythms are up for grabs; the works are only playable if one already knows the piece. Sanseverino, on the heels of Montesardo, resolves the issue of rhythmic ambiguity and he also verbally articulates what previously has been implied by Montesardo's notation system - that is, the dominant role that harmony plays in this guitar literature. He postulates that "it seems to me that the Spanish guitar ought to be played with full strokes and not otherwise... [since plucking] removes entirely the harmony." "Abatessa and Colonna subsequently explore further harmonic possibilities with "shifted chords" (what we now call "bar chords") than can be slid up and down the neck of the guitar to any location. They also compose short harmonic loops as a form of variation; Abatessa and Colonna embellish harmonies through the use of "satellite chords," brief chordal excursions that are caught in the orbit of the original chord and revolve around it as a sort of temporary harmonic center. ${ }^{5}$ Once again, we see the conceptual shift from melody to harmony; whereas Renaissance composers had viewed embellishment as the addition of florid runs that decorate the melody, Abatessa's and Colonna's embellishments are fully chordal, where active chord changes spin around the chordal contour.

To further spice up the harmonic palette, several guitarists present chord symbols that are embedded with dissonances. Foriano Pico in his Nuova scelta di sonate per la chitarra spagnola, flavors his compositions with unstable, dissonant chords that he labels lettere tagliati - and which subsequent authors sometimes call lettere false, alfabeto falso, or alfabeto disonante. ${ }^{6}$ Similarly, Pietro Millioni's and Lodovico Monte's new additions to the alfabeto system employ wildly dissonant, spunky harmonies that they identify as "newly invented, extraordinary alphabet chords" (alfabeto straordinario nuovamente inventato) (see Example 10.1).?

Even Berlioz, Wagner; or Liszt would be hard pressed to match their harmonic daring. What is particularly striking is that the harmonic dissonance 
is not something that arises from careful voice leading, but is instead all autonomous property of these chord shapes. They are made to be charged with dissonance; the art of preparing and resolving them seems to be of secondary importance. Stefano Pesori and Giovanni Paolo Foscarini incorporate appoggiaturas and fluid passing tones into their chord progressionsusually by moving fingers on the first and second courses - in a kind of "mixed tablature" that fuses together elements of both the newer chordal alfabeto system with the individual note placements made possible in the older lute tablature. These "altered alfabeto" chords are interpolated between stable triads, and as chords are slightly altered and restored, the rudimentary elements of melody begin peeking out of the texture once again. ${ }^{8}$

The elegant interplay between strummed and plucked styles found in Foscarini's fifth book served as a model for Francesco Corbetta's transition to the mixed style in his second publication, the Varii capricciper la ghitarra spagnola (Milan, 1643). In the hands of Corbetta, at last the guitar was elevated from the level of an amateur's hobby to that of a virtuoso instrument. It would be hard to overemplasize the role Corbetta played in promoting the guitar as an instrument worthy of serious study and development across the European continent. He brought together and synthesized the two disparate worlds of the lute and the guitar: he maintained the strummed techniques from the early guitar's genesis (rich in their vertical harmonies) and wove into that texture the single melodic notes and momentary counterpoint from the lutenist's realm. These mixed elements, first distilled by Foscarini and Corbetta, were then perfected by subsequent masters such as Bartolotti, Roncalli, de Visée, Campion, Murcia, Le Cocq, and Sanz - and in their hands the mixed style survived up to the middle of the 1700s when the Classical aesthetic supplanted that of the Baroque.

\section{Baroque vs. classical guitar}

The baroque guitar differs dramatically from its younger sibling, the six-string "classical guitar." 10 Its body is much smaller with a reduced string length, and the curvature of the upper and lower bouts is more slender. Instead of employing the "fan bracing" developed by Antonio Torres in the nineteenth century, the baroque guitar uses a simple pair of parallel braces running on either side of the sound hole - producing a much lighter and introspective sonority (see the chapter by Stewart Pollens in this volume for detailed technical information on baroque guitar construction). The baroque guitar ideally utilizes light-tension gut strings that give a translucent sparkle to the instrument; its crystalline sonorities are further "lightened" 
in some tunings in which bass strings (bordones) are few or absent altogether. Like those of the lute, the baroque guitar's strings leave the bridge directly from holes drilled in the bridge. This system differs substantially from the modern classical guitar's where the strings, having left the bridge's drilled holes, must then immediately ascend over a small piece of ivory (or plastic) called a saddle. Although visually small, this addition gives the modern guitar an enormous boost in sound volume, for once a string is plucked, the vibrations are efficiently transmitted into the guitar's soundboard via the saddle. On the baroque guitar, however, much of a string's energy is absorbed by the bridge without directly motivating the soundboard.

Whereas the classical guitar's range spans several octaves, its six single strings extending from the bass to the soprano registers, the baroque guitar's range is more constrained; it employs five courses rather than six (a course being either a single string or a pair of strings that are grouped so closely that they comprise one performable unit). The first course is usually a single $e^{1}$ (its singing clarity earning it the name of cantino or chanterelle) with the remaining eight strings being spaced together into four pairs. On the surface, all the baroque guitar's standard tunings resemble the modern guitar's first five strings that descend in order: $\mathrm{e}^{1}$ bgda. One baroque tuning replicates the modern guitar with its uninterrupted descent from high- to low-sounding strings (see Example 10.2a). On the other hand, the baroque guitar offered other options that result in lighter textures. One popular tuning, for instance, abandons bass sonorities altogether and advocates the exclusive use of highpitched treble strings. ${ }^{11}$ In this tuning, beginning with the first course, the pitches descend from $e^{1}$ to $b$ to $g$ (like the modern guitar), but then suddenly leap upwards to a treble $\mathrm{d}^{1}$ and a - thus making the $g$ on the third course the lowest-sounding note on the instrument (see Example 10.2b). Some guitarists identify this stringing as "re-entrant" tuning, since the treble sounds initially descend but then later "re-enter" as one strums across the instrument. Another tuning splits the fourth and fifth courses into octaves with each of them having both a treble and a bass string; thus a $\mathrm{d}^{1}$ is grouped with a d on the fourth course, and an a is coupled with an A on course 5 (see Example 10.2c). Still another tuning arose that was particularly adored by the French and other guitarists within the orbit of French influence; this solution employs the octave split on the fourth course and a pair of unison treble strings on the fifth course. For this last tuning, the lowestsounding note is the bass $\mathrm{d}$ on the fourth course (see Example 10.2d). Lastly, a handful of instrumentalists employed yet another tuning in which the third course is split into octaves; the highest-sounding $g^{1}$ soars above its neighbors (see Example 10.2e)..$^{12}$

These distinctions between the modern and baroque guitars are not 
(a)

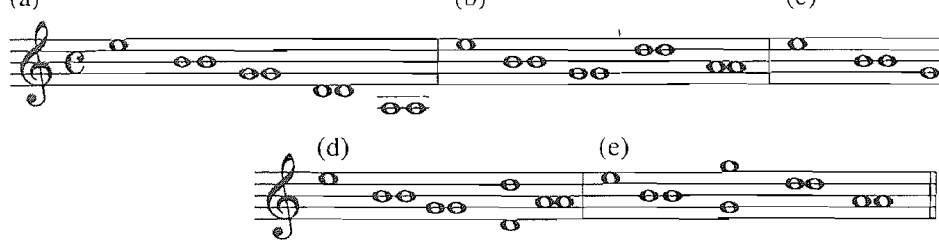

mere academic curiosities; they lie at the heart of different artistic sensibilities. The classical guitar is perfectly designed for polyphony and the interweaving of separate contrapuntal lines. The baroque guitar is designed for homophony and is ideal as a strummed chordal instrument. The bulk of classical guitar literature is for solo performance with the spotlight on the individual rather than the ensemble. In the baroque, these preferences are inverted; the sparkling tinkle of the baroque guitar was a standard element of ensemble performance (as evidenced by the nearly obligatory sections on accompanying in baroque guitar manuals). The sound qualities of the baroque guitar and classical guitar are worlds apart: the classical guitar is imposing and resonant; the baroque is introspective and delicate.

\section{Ornamentation, strumming and other effects}

It was this sparkling world of delicacy that became the core of baroque guitar literature. A perusal of baroque guitar books reveals a fascination with "flavor" or color. Even from the outset, when technique concentrated on strumming rather than plucking, guitar ists already presented a myriad of different effects such as the repicco and trillo. Pietro Millioni in 1627 describes the rather complex strumming technique known as repicco in which the thumb and middle finger strum downwards, and then the thumb returns in an upwards direction along with the index finger which plucks the first string rather than enveloping all the courses. There is a flurry of undulating sonority followed by the index finger's single melodic note that rings out above the texture. ${ }^{13}$ Similarly, the trillo (which has no relationship to the melodic trill) employed the index finger in a rapid up-and-down strum. ${ }^{14}$ The strumming techniques or batterie reached new heights in Francesco Corbetta's La Guitarre royalle dediée au Roy de la Grande Bretagne (Paris, 1671). ${ }^{15}$ He uses stems of various lengths to indicate which finger of the right hand strums; in his "Caprice de chacone," Corbetta fashions a torrent of cascading strums that foreshadow the energetic fervor of a modern flamenco bulerías. ${ }^{16}$ 
In later repertoire where individual notes are plucked, ornamentation abounds, and each phrase - sometimes each note - is given a different nuance or "flavor." More than any other feature, it is the variety of flavored shadings that motivated the baroque guitar aesthetics in the last half of the seventeenth century. Francisco Gueráu, for example, decorates almost every available pitch with adornments, and he verbally emphasizes the importance of ornamentation in his introductory comments to his Poema harmónico (1694). ${ }^{17}$ In his "Advice to Beginners," Gueráu elucidates the rudiments of performance technique, the way to read tablature notation, and the way to play ornaments such as slurs (extrasinos), trills (trinos or aleados), mordents (mordentes), and vibrato (temblor). At the conclusion of his explication, he sums up the indispensable role of ornamentation by stating:

These performance tips that I have explained - as well as ones that I will not address - are required by the guitar of anyone who might wish to play it with some skill. And although all of these points are essential for a good result, that which is the most gorgeous and causes the most harmony is the persistence of the trill, mordent, slur, and arpeggio. And although it is true that it will sound just fine if one plays good music in rhythm on an instrument that is in ture, nevertheless, by using these adormments which are the heart and soul of music - you will see the difference between one [good] performance and the other. ${ }^{18}$

Other guitarists cover similar territory in their tablature books, praising the effects of ornamentation and providing detailed lists of the specific adornments or agréments. Francesco Corbetta's La Guitarre royalle maps out the proper execution of ornaments (explaining them in both Italian and French), covering the trill (tremblement or tremolo), appoggiatura (cheute or abelimento), slur (roullement or strascio), mordent (martellement or rebatimento), vibrato (flattement or tremolo sforzato), cadence figures (cadenses or cadenzze), and the sustaining of a pitch (tenüe or tenute). ${ }^{19}$ Nearly every other prominent guitarist ventures into the same collage of sonorities, some even exploring further refinements such as the different sonority evoked by different right-hand fingerings. ${ }^{20}$ Robert de Visée and Nicolas Derosier prescribe which right-hand finger executes any given gesture, and they clearly are attuned to multifarious and subtle distinctions caused by different-sized fingers and the different timbres produced by fingertips and fingernails. ${ }^{21}$ A finger's downstroke emphasizes the crisp attack of the nail against the string, whereas the same finger in an upstroke elicits a warmer grouping of overtones as the broad flesh of the finger brushes by the string. The thumb's pudgy width and its strength produces a rotund and forceful sound compared to the narrower and brighter-sounding index finger 
whose crispness is preferred by de Visée at final cadences. Nuanced colors apply to the playing of chords as well: sometimes a chord's notes are simultaneously plucked and at other times they are rolled in a gentle arpeggio. At times a chord is enunciated by the crisp, downward stroke of the fingernail, and at other times the guitarist produces a mellower strum by the soft flesh of the thumb as it descends across the strings. In short, subtle variance of timbre is the aesthetic prize. This is in direct opposition to the Classical aesthetic where consistency of timbre was the desirable goal; for classical guitarists, the melodic line is a unified thread - much like a strand of spaghetti. For baroque guitarists, however, an elegant musical phrase should be rich in nuanced timbres, each note and each chord having its own color and articulation - rather like a salad of diverse and refreshing flavors that somehow blend and combine according to the whim of the chef.

And de Visée carefully arranges the fingerings to bring out the proper octave of a course; that is, his specific choices result in a finger striking harder the particular string of the pair that will best maintain smooth voice leading in the context of the phrase. When the bass string is to dominate, he has the index finger strike in an upward direction, bringing out the bordon (for it is strung closest to the floor'). If he wants the treble to penetrate, he selects the thumb - which will strike the treble string initially and with greater force.

Several artists explore more adventuresome timbral options. Santiago de Murcia employs a percussive golpe - presumably the striking of the guitar top with the right hand - in his lively setting of the African-American cumbe..22 One of the most spectacular and novel effects peculiar to the baroque guitar is campanelas (bell-like runs), made possible by the instrument's re-entrant tuning. ${ }^{23}$ Since the five courses all have strings that sound in the same octave, the guitarist is therefore able to play ascending or descending scales in stepwise motion merely by changing strings, not by depressing notes with the left hand as is necessary on the modern gujtar. Since consecutive pitches are played on different strings, they continue to ring in a bell-like effect (hence the name campanelas, derived fiom the word campana meaning "bell"). The glittering notes race by but continue to project in much the same way that un-stopped sounds continue to resonate in a piano when one depresses the damper pedal. The effect is stunning, and one has only to look at the splendid lines in the works of Gaspar Sant, Bartolotti, or Santiago de Murcia to see what a breathtaking effect it can be. Sadly, campanelas is impossible on the modern classical guitar since the rapid shifting between strings generates all sorts of octave displacements that preclude any linear melodic movement. 


\section{Accompanying}

Yet another element reinforcing the guitar's role in the revolution from polyphony to homophony around 1600 was its incessant appearance as an accompanying instrument. New styles and social contexts required chordal accompaniments, and few instruments were better suited than the guitar. Throughout the Baroque, the guitar thrived in both the courtly and the popular milieu - in the tavern, at the palace, or in the plaza. It was the quintessential accompanying instrument, and in that respect its role differs dramatically from that of the modern classical guitar. Whereas a modern guitarist has to scramble to find first-rate ensemble literature, the baroque guitar was as much a part of mainstream ensemble playing as the harpsichord or organ. Most guitarists addressed accompanying in a substantial way, and many - such as Corbetta, Granata, Matteis, Murcia, Doizi de Velasco, Campion, and Sanz - wrote perceptively on the figured bass and the art of accompanying. ${ }^{24}$

The critical role of accompanying in guitar literature is apparent from the first moments of the Baroque. If one peruses Italian publications of Italian homophony from the first half of the seventeenth century, one finds as nearly obligatory the presence of guitar alfabeto letters above the melody to facilitate chordal strumming. ${ }^{25}$ Girolamo Montesardo - an accomplished vocalist himself and the very same individual who was first to publish a guitar book utilizing the alfabeto system - sent to press an impressive collection of vocal pieces, I lieti giomi di Napoli (1612), that included accompanying guitar chords over the bass line. ${ }^{26}$ Similarly, Kapsberger, Falconieri, and Vitali meticulously place the alfabeto chords over the basso continuo lines in their vocal publications in the early decades of the seventeenth century. ${ }^{27}$ Undoubtedly, the proper accompaniment for these delightful works should include the strummed guitar as part of the musical texture. For the aforementioned artists who were accomplished and erudite musicians, errors in guitar indications are infrequent. But the rage for accompanied vocal songs spurred lesser talents into the arena as well. Sometimes, an author's flimsy understanding of music theory results in alfabeto accompaniments that are rather laughable. One such fiasco occurs in Abatessa's song arrangements in the Cespuglio di varii fiori (1635) in which all bass notes are harmonized as if they were root position chords, and he cannot figure out the difference between major and minor chords. ${ }^{28}$ Of course, Abatessa's ineptitude is the exception rather than the rule.

As the Baroque unfolded, several major artists continued to devote considerable attention to the guitar as the accompanying instrument for vocal music. Giovanni Casalotti's "Villanelle di più sorte," a gargantuan tome typical of these compendiums, presents al most 200 songs. ${ }^{29}$ Similarly, Ms. 2804 
in the Biblioteca Riccardiana contains 173 texted songs, here identifed as passcagli. ${ }^{30}$ Vocal accompaniments occur in baroque guitar books with the exquisite craftsmanship of virtuosi such as Corbetta in his Gutiarre royalle (1671) and Henry Grenerin in his Livre de guitarre (1680). ${ }^{31}$

\section{The baroque guitar and the theater}

The stage played a role equal to song in the performing life of baroque guitarists. During the late seventeenth and eighteenth centuries, the guitar remained a mainstay of the Spanish stage and performed at most comedias, either during the play itself or in the small musical skits that were customarily inserted between the main acts. ${ }^{32}$ Before the play's opening act, the players usually presented a brief loa (a sort of preface without any direct bearing on the drama that was to ensue); after Act I either an entremés (entr'acte) or a jácaras was mounted. An entremés normally involved a brief comic plot with a song or two that often were accompanied by dancing. Not infrequently, the characters mercilessly skewer prominent officials in their witty banter and riotous pranks. The jácaras was a specific subgenre of entr'acte in which the personages were lovable ruffians or peasants who found themselves in some predicament or humorous setting. Even if the playlet's text does not label a piece specifically as a jácaras, its style can be implied by the characters' names in the libretto. Escarramán, Zurdo, Zurdillo, and Clarín are stereotypical jaques - likeable servants, blind beggars, or low-life scoundrels in trouble with the law - and most often when their names appear, one can expect the music accompanying their antics to be a jacaras. Between Acts II and III, the single member of the cast or the whole troupe could present yet another short theatrical number, this time the baile or dance scene. As its title suggests, it could be based on any of the popular dances of the time, usually folkloric or "regular" everyday dancing as opposed to aristocratic courtly dance or ballet. It represents "popular" street culture, not pageantry. And after Act III, to conclude the evening's entertainment, the theater troupe could tack on a mojiganga or fin de fiesta. The mojiganga characteristically featured performers with outlandish masks, animal costumes or extravagant disguises - much like the fantastical costumes worn at Mardi Gras.

In Spain, the standard theater band for a Golden-Age play consisted of the baroque guitar coupled with either the harp or violon (a term which could imply violin as well as cello). ${ }^{33}$ Several theater troupes graced the stages of the three theaters in eighteenth-century Madrid (the Teatro del Príncipe, Teatro de la Cruz, and Caños del Peral), and they habitually brought with them a small ensemble of two or three musicjans, which almost always included the guitar. The theater troupe of Juan Bautista Chavarría featured a band with Chavarría on harp and Juan de Serqueira on guitar. The reputable musicians 
working the theaters or coliseos included guitarists Serqueira, Pedro de Castro, and Joseph de Salas; the star harpists were Chavarría and Manuel de Ferreyra; and the violon parts were deftly played by Juan de Chaves, Salvador de Navas, or Pedro de Castro. Remarkably, to this day, that baroque combination of harp and baroque guitar (now called a jarana) - and even much of the repertoire from its Baroque ancestry - thrives in the folk music of Veracruz, Mexico. ${ }^{34}$ The masterly Spanish guitarist and theorist Santiago de Murcia was probably the composer for the theatrical works by Francisco de Castro, Spain's most important playwright in the opening decades of the eighteenth century. ${ }^{35}$ His guitar teacher, the phenomenal Francisco Gueráu, also penned dramatic works: one might reasonably assume that the guitar found its way into Gueráu's accompanying ensembles. ${ }^{36}$

In France, too, the guitar was an indispensable part of the opera and ballet orchestra. Lully's and Campra's luxuriant stage works include guitarists repeatedly and in multiple contexts, and the guitar parts were surely played with aplomb given that Corbetta, de Visée, Grenerin, and Campion were all involved with theatrical productions. One can imagine the splendor and thrill when Corbetta himself strolled onto stage leading a group of guitarists in the première of Lully's Ballet de la galanterie du temps in $1656 .{ }^{37}$ Henry Grenerin, yet another master of guitar and theorbo, played in Lully's Ballet de Psyché and the Ballet royal de l'mpatience (1661). ${ }^{38}$ De Visée, who studied under Corbetta's tutelage, ascended to unprecedented heights in his compositional subtlety and skill; he too was intimately involved with Lully's sumptuous productions, as is evidenced by the large number of Lully transcriptions in de Visée's tablature books. ${ }^{39}$ Guitarists continued playing excerpts from French masterpieces long after the original theatrical works closed - well into the 1700s. As far away as Mexico and California, Campra and Lully comprised part of the core instrumental literature, as is illustrated by the numerous "fake books" or anthologies found in the New World that have Lully and Campra peppered throughout their pages. A list of top hits indicates that any self-respecting guitarist would have been able to launch into Campra's "Amable" from Hésione or the Bourée from Lully and Colasse's Achilles at a moment's notice. ${ }^{40}$

\section{Baroque dance and the guitar}

After song and stage, dance occupied a third critical area for guitar accompaniment. The Italian tablature books are chock-full of dance genres such as the balleto, brando, corrente, sarabanda, alemanda, and giga. Their binary constructions place the double bar halfway through or slightly before the midpoint. The French have corresponding cousins in the allemande, courante, sarabande, gigue, bourée, gavotte, menuet, etc. Of course, a good deal 
of this repertoire is dance-inspired, but not necessarily intended for dance accompaniment. ${ }^{41}$

That is not the case, however, with the copious settings of French danses à deux and contredanses, which are "practical" and utilitarian in nature. The danse à deux took Europe by storm in the late seventeenth and early eighteenth centuries. For people of high social station, it was all the rage, and the aristocracy expended countless hours in the time-consuming task of learning each new dance as it rolled off the press of Raoul-Auger Feuillet in Paris. Feuillet and Pierre Beauchamp solved the thorny problems of dance notation so that entire choreographies (including foot placement, hand motions, arm movement, etc.) could be realized and reconstructed solely by using abstract symbols rather than relying on verbose, meticulous textual descriptions or realistic graphic depictions of dancers. Feuillet's ingenious system, like music notation, was abstract, adaptable, and reasonably selfsufficient. In the danse à deux, a single couple dances at a time (unlike group dances where many couples simultaneously participate) etching out elegant, symmetrical patterns that are directed toward the "presence" - an important spectator such as the king or some other imposing royal person. Each new dance carefully joined choreography to a particular accompaniment for every measure of music, the couple had to memorize the specific step patterns uniquely designed for that location. Thus, it did not help much to know last year's repertoire; it was irrelevant. But as soon as a new dance arrived from France, the studious dancers had to start from scratch once again to memorize each of its choreographic instructions. The task was never-ending. Feuillet's press issued four to six danses à deux a year, and dancing fans eagerly sought them out as fast as they rolled off the press - in a sense, the danse à deux was the "rock and roll" of the era.

The guitar was at the center of this fad. Countless manuscripts and publications from the early 1700 s embrace danse à deux settings, and it is clear they were intended for actual accompaniment. No source better illustrates the utilitarian role of the guitar's accompanying function for danses à deux than Santiago de Murcia's Resumen de acompañar la parte con la guitarra (17 14). ${ }^{42}$ If one compares the "Catalogue" of Feuillet's available publications with the table of contents of Murcia's Resumen, one finds they progress along chronologically in an identical fashion(see Plate 18 and Table 10.1). ${ }^{43}$ This ordering would have made perfect sense for practicing performers of the time who surely would have known the year that a particular tune had been released - in much the same way that modern pop performers who make a living playing cover versions of Billboard hits can easily tell you the year that a pop tune hit the charts. In short, Murcia's Resumen de acompañar is a veritable jazz "fake-book" that supplied the necessary information for guitarists who played at danses à deux functions. 
Table 10.1 Comparison of the contents of Feuillet's Catalogue des Livres de Danses with Murcia's Resumen de acompañar la parte (1714)

\begin{tabular}{|c|c|c|c|}
\hline Feuillet's Catalogue & Murcia's Resumen (1714) & Page & [Composer] \\
\hline \multicolumn{4}{|l|}{ Scavoir } \\
\hline Le Livre de la Chorégraphie & - & & \\
\hline \multicolumn{4}{|l|}{ Le gros Recüeil... de Mr Pécour } \\
\hline La Bourée d'Achille & La Buree de Chil & 58 & Lully/Colasse \\
\hline La Mariée & La Mariee (with its "Giga") & 58 & Lully \\
\hline Le Passepied & Paspied Viejo & 57 & \\
\hline La Contredance & Otra Giga & 60 & Lully \\
\hline Le Rigaudon & Rigodon (with "Otro" [Rigodon]) & 61 & \\
\hline La Bourgogne & La Bourgogne & 61 & \\
\hline La Savoye (Bourée) & La Saboyana Buree & 63 & \\
\hline La Forlana & La ferlana & 63 & Campra \\
\hline La Conty (Venitenne) & La Contij & 64 & Campra \\
\hline \multicolumn{4}{|l|}{ Danses de Bal } \\
\hline La Pavanne des Saisons $\lfloor 1700 \mid$ & La Pabana des Sesons & 65 & Lully \\
\hline Le Passe-Pié Nouveau [1700] & Paspied Nuebo & 57 & \\
\hline I'Aimable Vainqueur [1701] & La Amable Despalci]o & 66 & Campra \\
\hline I'Allemande [1702] & La Alemanda & 67 & Campra/Lully \\
\hline \multicolumn{4}{|l|}{ Petits Recüeils Annuels } \\
\hline la Païsanne (1703) & Los Paysanos & 66 & \\
\hline Jes Contrefaiseur Contredanse ( 1703 ) & & - & \\
\hline la Saltarelle (1704) & La Saltarele & 68 & Campra \\
\hline la Carignan (1704) & La Cariguan & 68 & Gillier \\
\hline la Madalena (1704) & La Madalena & 69 & \\
\hline la Babeth (1705) & La Babet & 70 & de la Barre \\
\hline la Bretagne (1705) & La Bretaignee Paspied & 70 & Campra \\
\hline la Triomphante (1705) & La Triumphante & $(84)$ & Campra/Lully \\
\hline la Baviere $(1706)$ & La Babiere. Menuet & 70 & de la Barre \\
\hline la Fanatique (1706) & La Marcha de Fanatiques & 71 & \\
\hline le Cotillon (1706) & El Cotillon & 71 & \\
\hline la Bacchante (1707) & La Bacante & 72 & La Coste \\
\hline la Matelotte (1707) & La Mathalote & 72 & Marais \\
\hline le Menuet a quatre (1707) & Le Menuel a quater & 72 & \\
\hline la Nouvelle Bourgogne (1708) & La Nueba Bergoña Paspied & 73 & \\
\hline la Nouvelle Mariee (1708) & La Nueba Mariee & 74 & Lully \\
\hline la Nouvelle Gaillarde (1709) & La Nueba Gallarda & 74 & \\
\hline le Menuet d'Alcide (1709) & El Menuet de Alcides & 75 & Lully/Marais \\
\hline le Charmant Vainqueur (1709) & La Charmant de Vainqueur Grave & 75 & \\
\hline Ia Bourbon $(1710)$ & La Borbon & 76 & Campra/Lully \\
\hline la petite Bourée $(1710)$ & La Pequeña Buree & 76 & \\
\hline la Gouastala (17]0) & La Guastala & 77 & \\
\hline la Nouvelle Forlansic (1711) & La Nueba Forlana & 77 & \\
\hline le Passepied ì quatre (1711) & El Paspied a quatro & 78 & \\
\hline la Medicis (1711) & Rondo La Medicis & 78 & \\
\hline la Silvie (1712) & La Silbia Grave & 79 & \\
\hline la Donbe (1712) & La Dombe & 80 & \\
\hline l'Asturicnne (1712) & La Asturiana Rigodon & 80 & \\
\hline la Melanie (1713) & La Melanie & 81 & \\
\hline la Denain (17!3) & La Denain & 81 & \\
\hline
\end{tabular}

The French aesthetic was not the only one that thrived in Spain in the early eighteenth century. For several centuries - beginning in the late $1500 \mathrm{~s}$ and continuing well into the mid-1700s - the Spanish delighted in two different families of indigenous dances (danzas and bailes) that were readily 
Catalogue des livkes dE DANSES

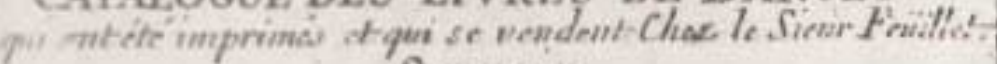
Scavour.

La Lire de la Chonigray his ou tár-de D Écric la

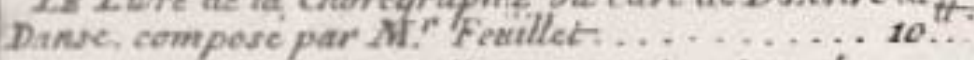
Legres Reriicil des meilieurses C'ntries de Balet de miscrour tank pour home que pour ferme..... 10."

\section{DANSRS DE BAL.}

Ia Pavanne des Saisons.

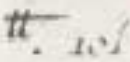

Ie Pnsye-pic Nowveau.

10.

Ijimakle ríninqueur.

10.

fAllemande.

. 13.

\section{Petims Recitens Anniets.}

PremerRecüil pour lanngé tro5. Contruant-

la Paisanne, it les Contrefueseur Controdanse, th 10 n

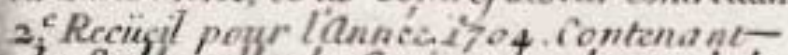

ta Saltarellc, la Carigman erla madalena. ,tso.

3. Recuiqul pour lannec 1705. Contenant

la Babeth la Brrtagne, et la Triomphann $2^{\text {th }}$ to. $4^{c}$ Reciecil pour lannec 1706. Contrnamla Baviere, la Furiatique ot le Cotillon..... 2t, 10 . 5 "Recieil po!" IUnnee 1707 . Contenant-

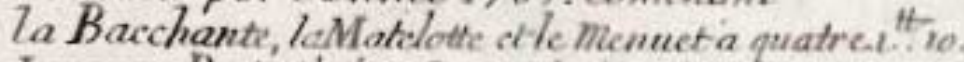
In gros Rerieil des Conrridansa Anglaver ct Francoures au nombre de brente deux. . 5.t. $6{ }^{\circ}$ Recieil pon Liannice 1708 . Contenantla Nouvelle Bourgogne, la nonuelle Marié, etsix Conftedan.ses. ..............t. $x^{\text {th }}$. 7. Recuicil pour lánné 1709 . Contenant le 7low: velle Gaillarde, te menuct dialcide, et le Chqrment-Vainqueur.

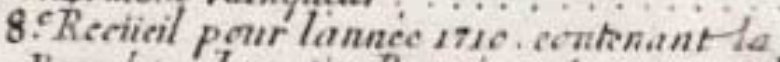

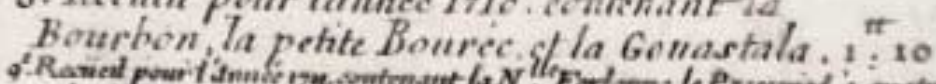

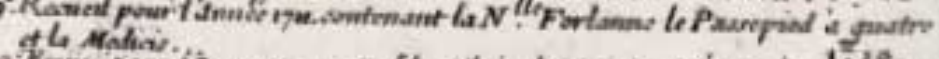

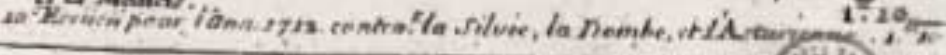




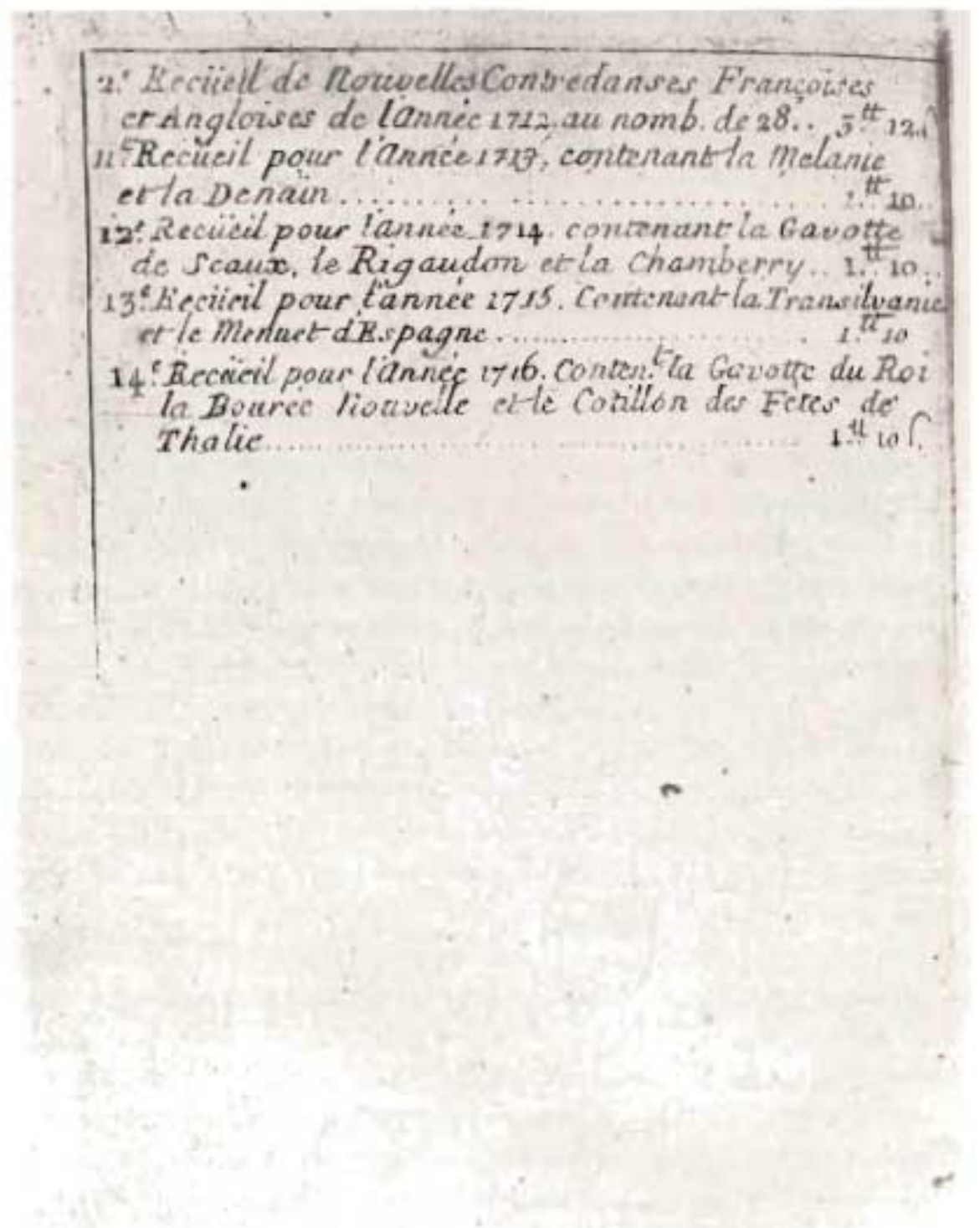


distinguishable from each other. ${ }^{44}$ On the one hand, danzas were rather subdued in nature (at least with regard to their choreography), were danced from the waist down with no upper body or hand motions, and were associated with the aristocratic upper classes. The bailes, in contrast, were rowdier in mood (often of a lascivious nature that could even approach the scandalous), were associated with the lower classes or even low-life scoundrels, and were performed with enticing and florid motions in the arms and hands. Bailes often were accompanied by the clatter of castanets, rattle of tambourines, or percussive drive of small hand drums, unlike the more restrained and demulcent danzas that normally precluded the use of hand percussion. The guitar books, beginning with Amat's and continuing through Murcia's, present the standard chord progressions for the plethora of bailes and danzas that were the rage in Spain and her colonies.

The performance of these Spanish dances represents the epitome of Baroque jazz - the guitarist spells out the chordal basis of the work by initially strumming through the well-known progression a few times (in much the same way that Bird Parker or Dizzy Gillespie would play the "head" of a particular composition) and then blasts off into wild flights of improvisational fancy in a series of diferencias (which would correspond to the "choruses" in a Parker or Gillespie jazz recording). Much of the notated repertoire in Spanish guitar books, then, consists of intabulated examples (that is, arranged for tablature) of sample variations - rather than "finished" and complete compositions.

For example, Sanz repeatedly gives a title and then provides only a phrase or two of music; they are tasty snippets but not complete meals. He would be shocked to see the modern-day performances of these musical hors d'oeuvres where the disparate dances are strung together into incongruous "suites" that change topics every twenty seconds and never elaborate or expand on a single idea. To play fifteen of these tiny segments one after another and then call it a "suite" would be rather like stringing together fifteen movie trailers into an hour-and-a-half, visual hodge-podge and then calling it a "film." Although the experience might even be pleasurable, it would not be typical or representative of modern cinematography. Similarly, a string of patched-together guitar improvisations (each improvisation based on a different harmonic progression) is not representative of the Spanish performance traditions during the Baroque.

\section{Improvisation}

Fortunately, we do have representative examples of the guitarist's improvisatory art that reveal the skills that were expected in the realization and 
performance of danzas and bailes. Some of the best examples of diferencia realization are found in an important manuscript located in Spain ${ }^{45}$ that anthologizes works by "the best authors." With the exception of several pieces by Francesco Corbetta and a handful also set by Santiago de Murcia, the lion's share of the manuscript is devoted to Gaspar Sanz's Instrucción de misica sobre la guitarra española (1674). Some of the selections are faithful copies of the Sanz originals, but more interesting are the numerous renditions that depart from them. Careful scrutiny of these two sources reveals that phrases are, in fact, modules that can be removed, inserted, and interchanged to create "new" pieces. The "Libro de diferentes cifras" lops off the fina] variations of Sanz's "Passacalle de la L." 46 Sometimes the opening strum patterns are excised (since it would have been implicit they were to be performed anyway), as in the reworked version of Sanz's "Passacalle de $3^{\circ}$ tono." 47 Near the middle of the piece, the order of two phrases is inverted. In a subsequent example, the "Libro de diferentes cifras" excises the strummed introduction to Sanz's "Passacalles por la C" and then launches directly into the heart of the piece. The manuscript meticulously copies the following three-and-a-half phrases from Sanz, but from that point forward the two versions diverge dramatically - they become different compositions. Here, Sanz's original diferencia composition serves as a springboard for a totally new creation.

Particularly fascinating is the "Libro de diferentes cifras" reworking of Sanz's "Jácaras"; it reveals the rich variety of possibilities in modular recomposition. The manipulation of phrases in this type of recomposition is not entirely arbitrary but generally follows certain patterns. One basic principle is that new modules can be generated from segments of other modules. For instance, a module can reappear several times in a work using the same beginning but spun out to a different end, as can be seen in the reworking of Sanz's Variations 2 and 5 (see Example 10.3).

Another manner of generating new phrases from old ones is to break the original into two parts and use the first as the beginning of a new module and the second as the end of another, forming a sort of musical parenthesis that creates two phrases from splitting one. Of particular interest here is the way the "Libro de diferentes cifras" draws out Variation 7 into two phrases. The campanelas beginning - which is the stylistic link to the campanelas conclusion of Variation 6 - remains unchanged, but the tail is transformed into a rapid, descending scale. The following variation uses as its conclusion the remainder of Variation 7 to lead back gracefully to the high tessitura of Variation 8 (see Example 10.4).

In this manner, all new material is inserted in such a way as to preserve the smooth transitions and essential qualities of the original.

Not only are properties of the original respected, but they are often emphasized and amplified in the reworked version. Sanz pushes to the climax 
170 Craig H. Russell

Example 10.3 Comparison of "Jácaras" phrases in Sanz and "Libro de diferentes cifras"
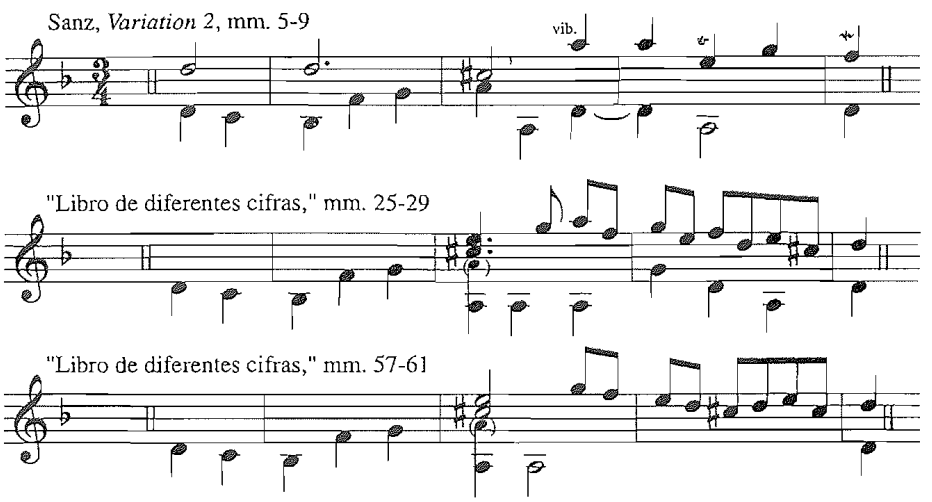

Sanz, Variation $5, \mathrm{~mm} .17-21$

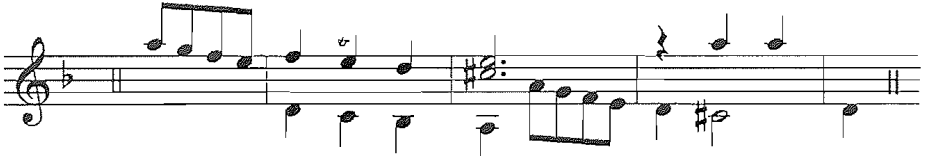

"Libro de diferentes cifras," mm. 5-9

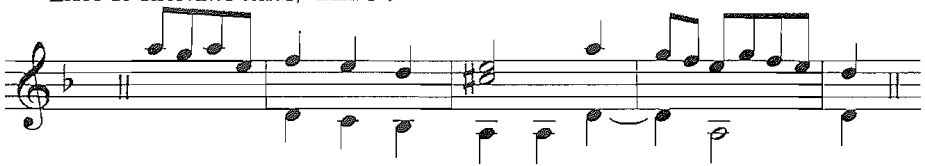

"Libro de diferentes cifras," mm. 17-21

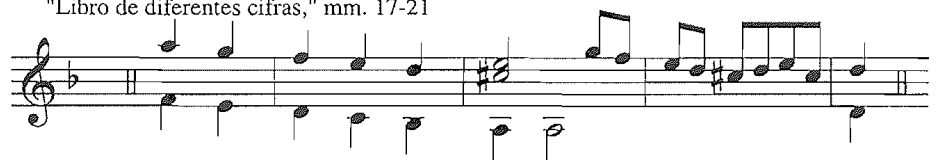

Example 10.4 Comparison of "Jácaras" phrases in Sanz and "Libro de diferentes cifras"
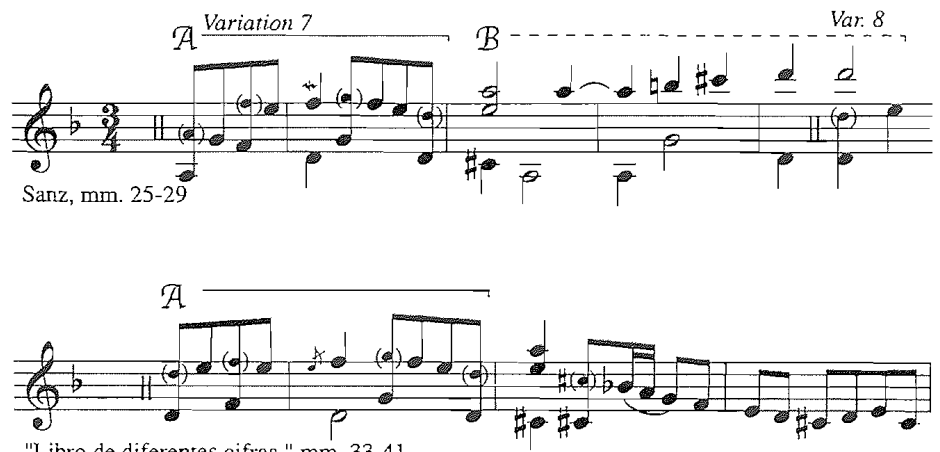

"Libro de diferentes cifras," mm. 33-41

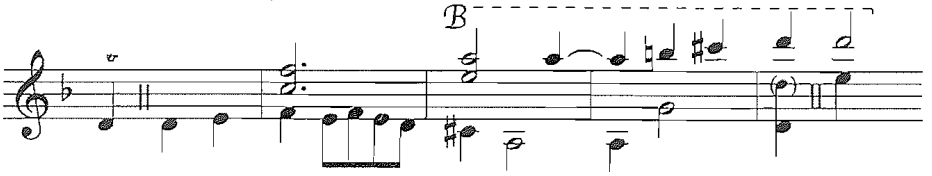


Example 10.5 Similar phrases in "Libro de diferentes cifras"

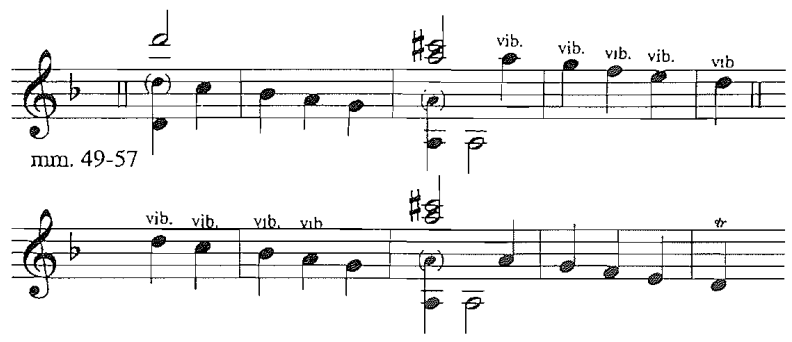

of the piece through a series of running scales (Variations 12 through 15). The "Libro de diferentes cifras" is careful not to break this drive to the climax, but even enhances the finale's strength by expanding this energetic section of fast scales from four to eight (mm. 66-96).

Only changes in vibrato and register distinguish two other variations from being identical twins (Example 10.5).

This example, and the previous ones, demonstrate decisively that a diferencia composition is not comprised of inviolable measures in a highly rigid order. Instead, it can be viewed as a smorgasbord of phrases that can be dropped off the menu at will - or can be supplanted with new phrases if so desired. A guitarist, then, would be expected to be fresh, original, and new; he or she would realize a particular baile or danza in different way with each performance opportunity.

\section{The social world of the baroque guitar}

The revolution in musical styles that we have already examined - the shift from a horizontal and melodic perspective to a vertical and harmonic oneoccurred simultaneously with socio-political shifts in perspective that were to rock society and shake the foundations of the privileged, aristocratic system. The guitar is one of the few instruments that saw itself climb up the social ladder, from a relatively low stature in the early Baroque to acceptance in high society by the late years of that epoch. In the early 1600s, it was considered the popular instrument of amateurs or low-lifes. Luis Briçeño, in the preface to his Método mui facilissino, defends his beloved instrument against its detractors who view the guitar as too lowly by stating:

There are many, my Lady, who ridicule the guitar and its sound. But if they pause and think about it, they will discover that for our present era, the guitar is the most favorable instrument that has ever been seen! For nowadays, if one is trying to save out-of-pocket expenses and trouble, the 
guitar is a true theatre of savings! In addition to this, it is adaptable and appropriate for singing and playing, for performing [noble] danzas, for accompanying leaping steps or ruhning ones, for accompanying [low-life] bailes, or for accompanying [hee]-clickingl tap dancing. ${ }^{4}$

The fad for guitar playing that swept Europe in the early 1600 s was viewed with ambivalence by those who, on the one hand, enjoyed its dulcet strums, but on the other hand saw the guitar's rising popularity as a potential scourge that was displacing more "high-minded" instruments. For instance, Lope de Vega and Cervantes tip their hats in respect to Vicente Espinel for his contributions to the guitar and its popularity. But even Lope, who had praised Espinel in his Caballero de Illescas (1602) and Laurel de Apolo (1630), nevertheless expresses his melancholic regret that Espinel's guitar innovations were overwhelming and supplanting aspects of more "noble" music. In Dorotea (1632), Lope laments, "God forgive Vicente Espinel for bringing us this novelty and the five-course guitar with which the noble instruments are being forgotten." 49

Musical theatre productions further clarify the social stereotypes that society held for guitarists. Typically, the cast performing bailes on stage to the sound of guitars are characters such as Zurdo, Zurdillo, Clarín, or Escarramán - all of whom are lovable, comical, low-class ruffians and scoundrels. And moving one step up on the social ladder, the guitar appears in the hands of menial craftsmen such as barbers. It is rare to see the guitar in the hands of the ruling aristocracy in the first decades of the seventeenth century.

But once the guitar fad began to sweep Europe, the instrument worked its way up the social ladder, rung by rung, until it was the darling of the nobility in the late 1600s. Nearly every crowned head of Europe knew a few chords and had a guitar virtuoso as a personal teacher. The real watershed in this area was Francesco Corbetta, whose private students or close acquaintances read like a "Who's Who in Seventeenth-Century Europe." Some of them include: Carlo II, the Duke of Mantua; Philip IV of Spain; Archduke Leopold Wilhelm of Austria; Duke George William of Zell at the Hanover Court; Charles Il of England; James, the Duke of York; Henrietta Anne, the Duchess of Orleans; and Louis XIV of France, with whom he had a lifelong friendship. ${ }^{50}$ The incomparable Francisco Gueráu occupied a place of importance in Carlos II's court in Madrid, and following the king's death in 1700 and the subsequent coronation of the first Bourbon king in Spain, Philip V, the guitar remained a part of daily life in the Spanish court. Gueráu's probable pupil, Santiago de Murcia, gave private instruction to the new Queen, Maria Luisa Gabriela of Savoy, and Antonio de Murcia was appointed official guitar maker for the monarchs. ${ }^{51}$ Other European courts lavished attention 
Example 10.6 Fandango rhythm

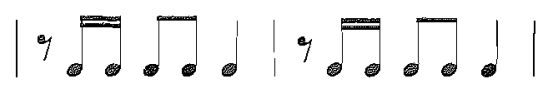

on their guitar instructors and makers. Clearly, the guitar was no longer relegated to the gutter.

Of particular interest is the way the guitar became adopted by the newest social class to rise to prominence in the late seventeenth and eighteenth centuries - the middle class. In the 1700s, the rise of egalitarian ideals in the Age of Reason and the concurrent rise of the middle class shook the foundations of the ailing aristocratic system. No instrument better illustrates those social revolutions than the guitar. The guitar was the working man's instrument. It was relatively inexpensive, highly portable, extremely popular, and easily learned with self-instruction books. Several of the guitar books flagrantly brag that they can teach an interested person how to play without their having to take lessons. ${ }^{52}$ The painters of the time, first Watteau and later Goya, place the guitar in the hands of ordinary people (rich, poor, or middle class) in nearly every imaginable setting and venue. ${ }^{53}$ New dance genres evolved that ruptured the barriers between danzas and bailes, and in each case, the new appeal was a common ground where the middle class, rich and poor, aristocrat and servant, could meet on equal footing. Among these social newcomers were the seguidillas, jota, sombras, and most important of all, the fandango. In each case, the preferred instrument for dancing accompaniment was the guitar. The earliest known musical settings of the fandango, jota, and seguidillas occur in Santiago de Murcia's "Códice Saldivar No. 4" for guitar. His setting of the fandango is one of the highlights of the guitar repertoire with its incessant, hypnotic alternation of D minor and A major chords, its infectious build-up in intensity, florid and virtuosic runs, and its recurring and driving rhythm. By the time fandangos were commonplace in the late eighteenth century, the genre had developed a cliché rhyth m that was inextricably associated with it (Example 10.6).

The fandango became the most beloved dance in early Californian history; countless depictions from the nineteenth century show the locals dancing up a storm to the sounds of guitars and castanets, and the caption most often reads "fandango." What better dance than the fandango to represent the rugged California spirit of the rancho period where success depended largely on self-reliance, independence, hard work, and a solid work ethicall values that reflect middle-class values as opposed to aristocratic ones. Not surprisingly, then, the fandango became the norm rather than the older and stuffier danzas. 
It is significant that the guitar - and the fandango - are the musical indicators that Mozart and his librettist da Ponte select when they cook up social revolution in their subversive opera The Marriage of Figaro (1786). When the servant Figaro sings the memorable aria "Se vuol ballare" early in Act I, he spells out the entire thesis of the plot, and he uses the guitar as the central metaphor for lower-class supremacy over the arrogant excesses of a self-indulgent aristocracy. Figaro, who sees through the shallow attempts of the Count to bed his wife's maid and Figaro's fiancée Susanna, sings in disgust that his employer the Count will have to match wits with none other than Figaro himself, the servant. Mozart's and Da Ponte's libretto runs, "If my dear Count you want to go dancing, then I will play the music on my guitar!"54 Social turmoil is subtly but unmistakably engendered in those lines. It is the lower-class barber Figaro - with his handy guitar - who will call the shots and play the tune, and the aristocratic Count will have to keep step to the music that the servant chooses. Brilliantly, to reinforce his point, Mozart disrupts the noble minuet rhythm that had begun the aria "Se vuol ballare" and then metaphorically trips the Count up by the sudden intrusion of a contredanse rhythm, a style associated more with the middle class than with the aristocracy. Thus the servant's contredanse literally drives out the aristocrat's minuet.

In the finale to Act III of Figaro, Susanna sets a trap for the unsuspecting Count by dropping a sealed note of feigned love for him to find while dancing. She supposedly will meet him in the garden for a midnight tryst, but we all know it will be his wife the Countess - not Susanna - who will be waiting for the faithless man. So, how does Mozart choose to get this clandestine note delivered? First, he opens the finale with a march that reflects the nobility and high station of the Count and Countess, which in turn is disrupted by a contredanse sung by peasant girls and the local servants. This, too, is then abruptly cut short by the strains of a fandango, and it is this universally appealing genre - one associated with the guitar - that Mozart cleverly uses as the meeting ground for Susanna and the Count. Mozart has prepared the scene by presenting the two classes as separate, non-overlapping entities. A servant girl would have been stepping above her station in an egregious way if she were to participate in the regal, majestic march that begins the scene. Similarly, the Count would never have stooped to dancing to the subsequent peasant dance. But finally, the new genre of the fandango is a meeting place where both nobles and peasants could participate; it is the great equalizer. Thus, it is during this fandango that Susanna has the opportunity to gain access to her master, the Count, and deliver the feigned confession of love that is so instrumental to the protagonists' scheming. The fandango marks the first moment in the finale where the two class structures could have interacted. Significantly, one finds the traditional and most representative 
rhythm of the fandango (articulated in m. 444) as the unifying rhythmic feature of Mozart's fandango as well.

\section{Cross-cultural aspects of the baroque guitar}

In addition to reflecting aspects of class and social structure, the guitar also provides a mirror for changes in the ethnic and cultural tapestry of Western civilization in the Baroque era. Before the late Renaissance, the various continents were relatively isolated from each other, but that changed forever in the 1500 s and 1600 s with the rapid proliferation of European claims on territory across the globe. The Portuguese, the first out of the starting blocks, explored the coast of Africa by solving the thorny problem of how to navigate in the Southern hemisphere (a frightening prospect initially since it necessitated crossing the Equator and losing sight of the Pole Star). The Spanish were soon to follow, and then the Italians. By the 1600s, nearly all of the European powers had constructed respectable navies and were staking claims to most of the Americas, Africa, Asia, and eventually Australia and the South Pacific. The great land grab was on. Once again, the guitar was carried along on naval vessels as a rule or even on overland expeditions, and it was one of the first instruments to be brought ashore in new lands. Not surprisingly, then, the guitar ended up as one of the indispensable ingredients in cultural hybrids that thrust together people and influences from various continents.

Beginning with the first voyages to the Americas, the guitar was the soldiers' and evangelists' true companion. ${ }^{55}$ With each new territorial claim, the Spanish brought with them this highly portable instrument. According to Bernal Díaz del Castillo, who accompanied Cortez on the conquest of Mexico, as early as 1568 the Native American craftsmen were already fabricating high-quality guitars or vihuelas. ${ }^{56}$ Bartholomé de las Casas recounts specific occasions on which guitar music resounded in the Caribbean as early as the $1530 s^{57}$ The Incan writer Guamán Poma provides invaluable descriptions that place the guitar in a rich web of peoples, social strata, and ethnicities, and also sketches out the earliest South American drawing of the guitar. ${ }^{58}$

It is the guitar, or its close cousins, for which the earliest African American instrumental manuscripts are written. The musical anthology compiled by Sebastian de Aguirre around 1700 (presently in the private archive of Gabriel Saldívar y Osorio), contains the "Portorrico de los negros por 1 y 2 ras Lguead]o" (fol. 20r); it is the oldest known example of African-American instrumental music. ${ }^{59}$ The Agurre manuscript contains a dozen other works that combine the influences of the Americas, Africa, 


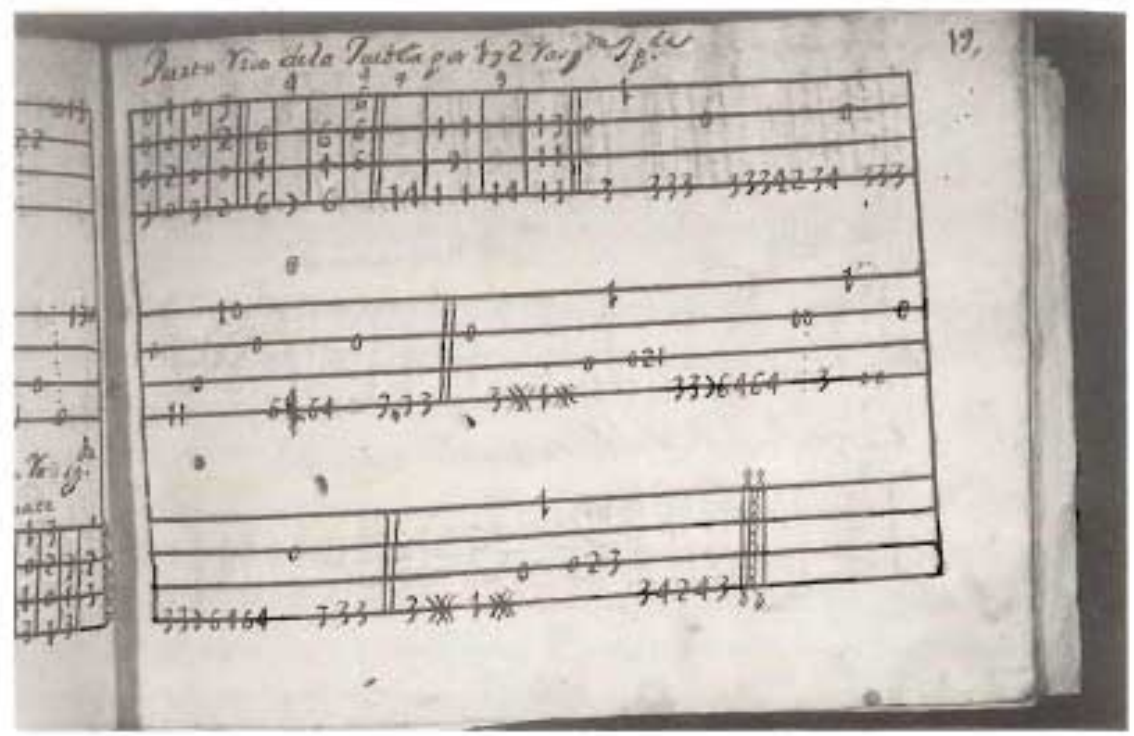

Plate 19a Aguirte Manuscript, fol. $19 \mathrm{r}$

and Spain (see Plates $19 \mathrm{a}-\mathrm{f}$ ). The classifications themselves reflect these exotic combinations of peoples and ethnicities. The tocotin, corrido, grasteco, and chiqueador reflect indigenous Mexican influence. ${ }^{60}$ The ttymology of corrido is unclear, but the term becomes associated with Mexican ballads in the subsequent century and becomes one of the great contributions of Mexican folklore to world culture. According to the poetess Sor luana Inés de la Cruz, the tocotin is nothing else but a corrido. A guasteco refers to a man from that region of Mexico. The chiqueador is a type of jewelry or adornment worn by Mexican women during the epoch; normally they were small, round discs carved from turtle or tortoise shells. ${ }^{61}$ It also is an American term that can mean "flatterer" or "pamperer" or someone who goes strutting about ${ }^{62}$ Other titles in Aguirre's book imply a Caribbean connection, such as the self-explanatory terms parama and porto rico ${ }^{63}$ In addition, perhaps "El Coquis" takes us to the Caribbean islands, since coquif in modern-day Cuba and Puerto Rico refers to a small reptile whose name derives from its cry that resembles the sound "coquí, coqui," ${ }^{\text {"Y }}$ Yet another cultural group surfaces with Aguirre's title "Morisca," which literally translated means "Moorish woman"; the term morisco was a common ethno-social appellation for a Moorish convert to Christianity. ${ }^{65}$ These brief musical snapshots, combined with the long list of traditional bailes and danzas that Aguirre inserts into his manuscript, provide one of the richest compendiums of multicultural influences and styles found in this (or any other) epoch.

The other gem of African American influence is Santiago de Murcia's "Códice Saldivar No. 4" (1732), for tucked into its folios are the African 


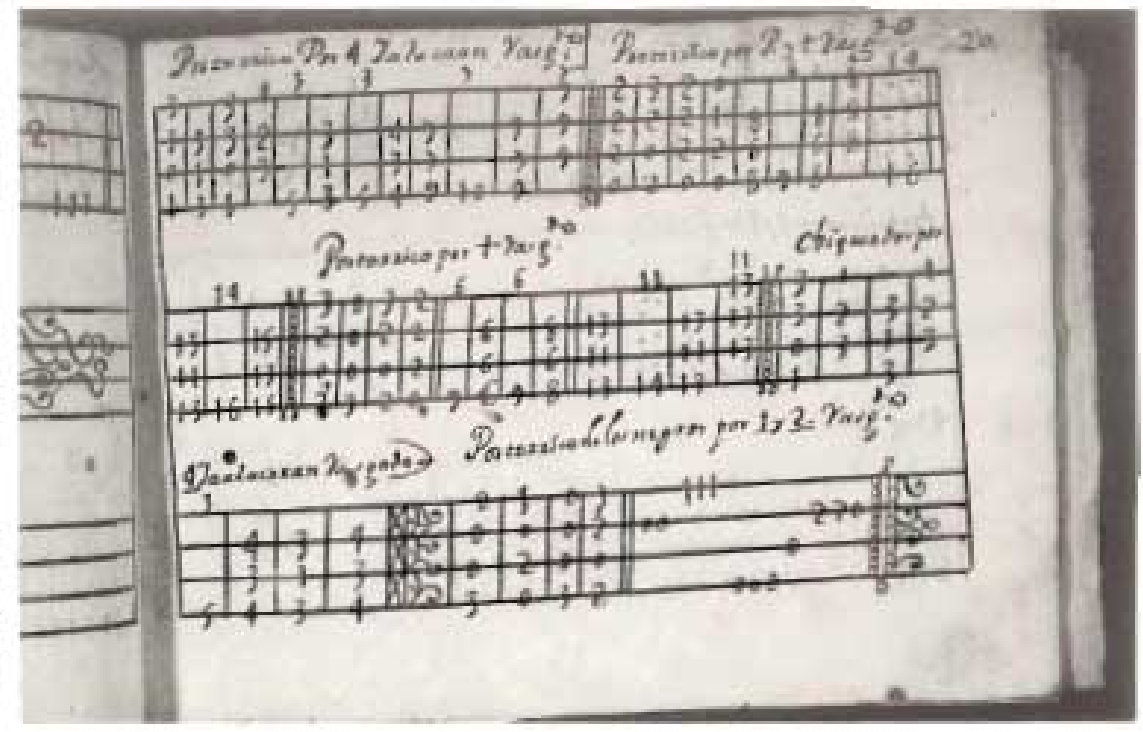

Plate 19b Aguitre Mantuscript, fol. $20 \mathrm{r}$

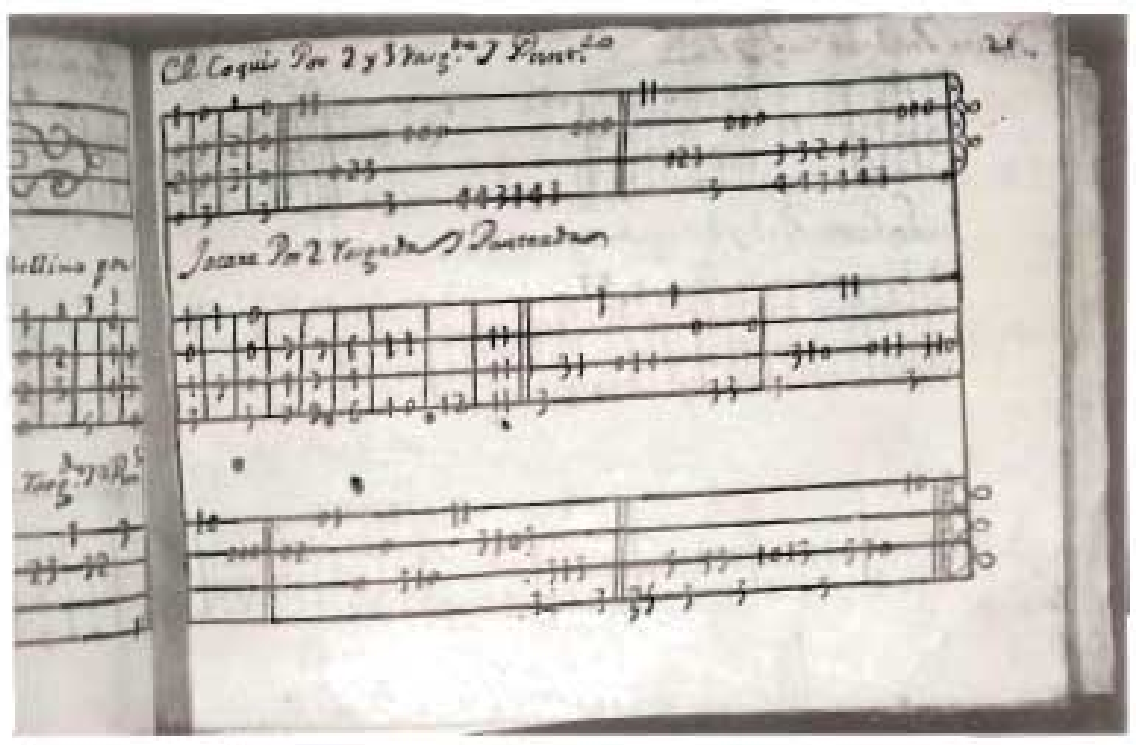

Plate 16c Iruire Manencript, fol zir

American "Cumbées" and "Zarambeques" (see Plates 20 a-b). ${ }^{66}$ Strong cvidence drawn from theatrical productions of the age suggest that the aummbeque, cumbe, and guines are one and the same-they refer to a class of dances of African-American origin that generally roll along in jaunty triple meter. are full of verve and subtlety, and are chock-full of syncopation. ${ }^{67}$ Like most 


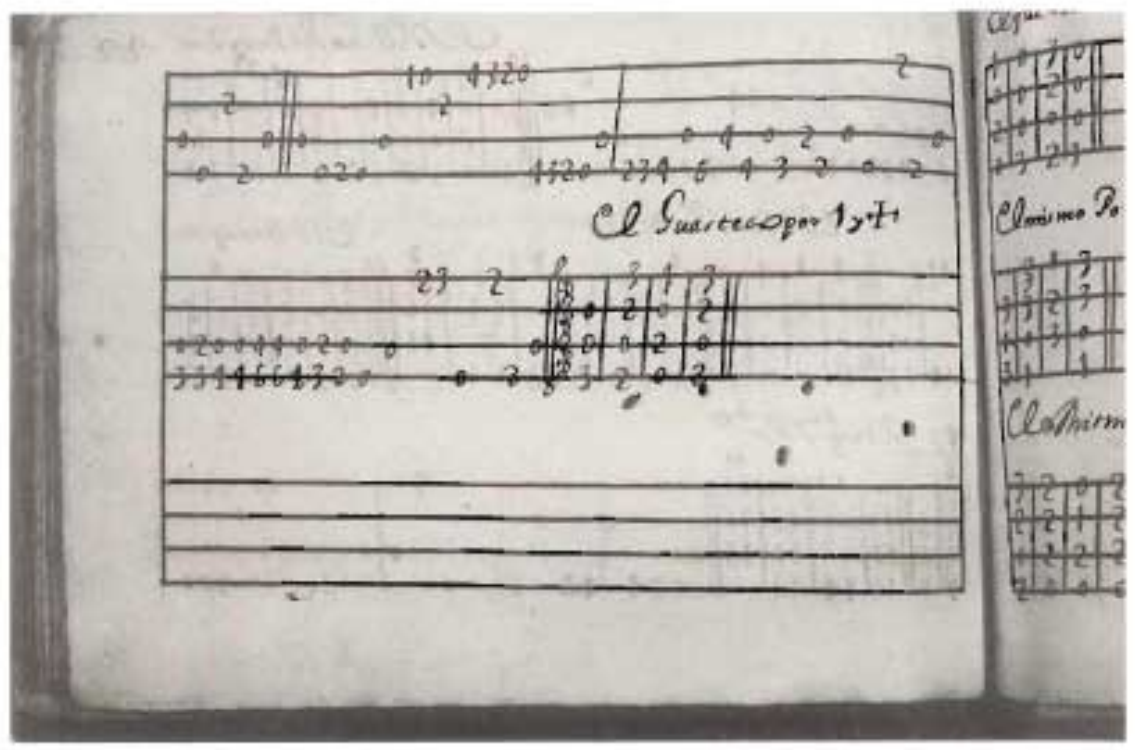

Plate 19d Aguirre Manuscript, fol. 22y

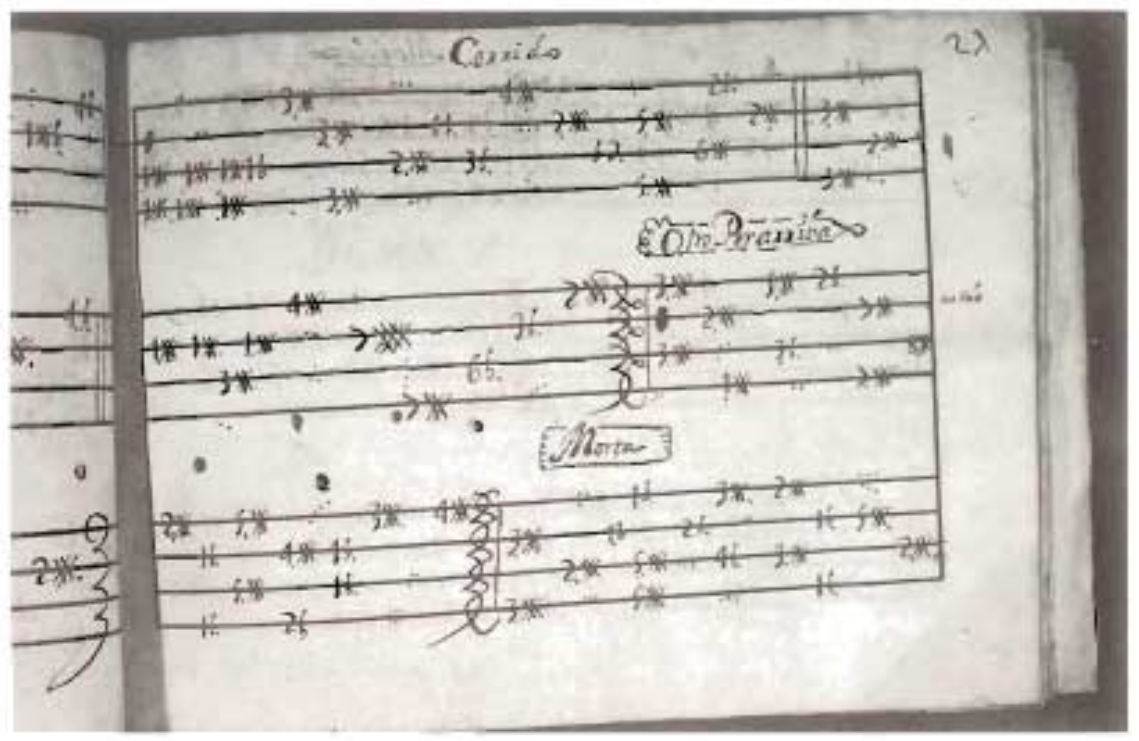

Plate 19e Aguirre Manuscript, foL 27r

popular dance styles, the same genres and styles also entered church performance through the secular-influenced villancico that took music from the street, cleaned it up slightly, and brought it into sacred church festivities, especially Matins services. Although the guineo (and by extension 


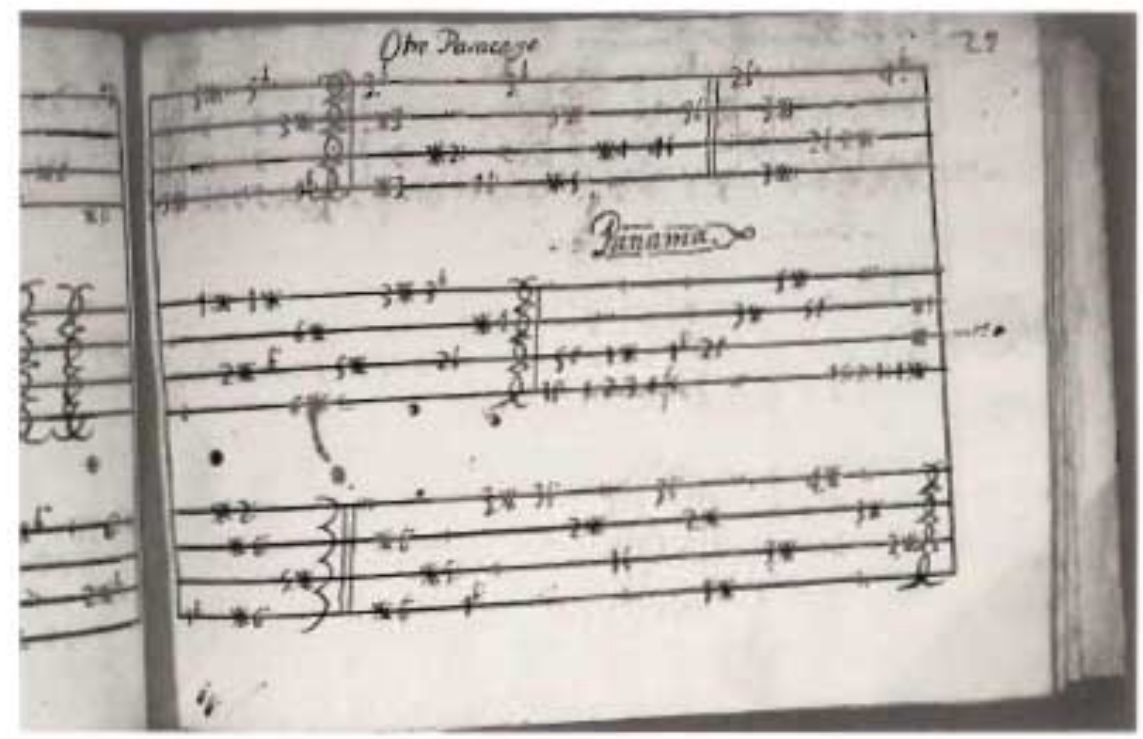

Plate 19f Aguirte Manuscript, fol. $29 \mathrm{r}$

the zarambeque) skyrocketed to the heights of popularity as a style of African-American villancico during the seventeenth century, this tablature rendition by Murcia is the first purely instrumental version of the genre.

But the true treasure of Murcia's manuscript is the infectious setting of the "Cumberes," the first truly decipherable example of instrumental music in an African American style. The dance was banned repeatedly by the Inquisition, to no avail, but the condemnations open a window for us to view the delightful fun that they must have been. The Inquisition rails against the cumbe in 1716 with the searing complaint that its "lyrics are scandalous, obscene, and offensive to the highest degree. They are sung and accompanied by a dance no less scandalous and obscene. They are accompanied by lewd actions, lascivious displays, and indecent and provocative shaking-all to the grave ruin and scandal of the souls of the Christian community!"6s Sounds like fun. In spite of this invective and many more, the cumbe enjoyed widespread popularity.

Murcia's setting of the cumbe begins with syncopated strums and golpes where the guitarist strikes the guitar top. The infectious beginning gradually gives way to the main tune and ensuing flights of fancy that are cast in evershifting hemiolas. The runs become increasingly frenetic and rapid, until the setting eventually concludes in a flurry of ecstatic scales and punctuating strums.

In conclusion, we see that the guitar - an instrument that in modern times is strongly associated with the social turmoil in American history of the 


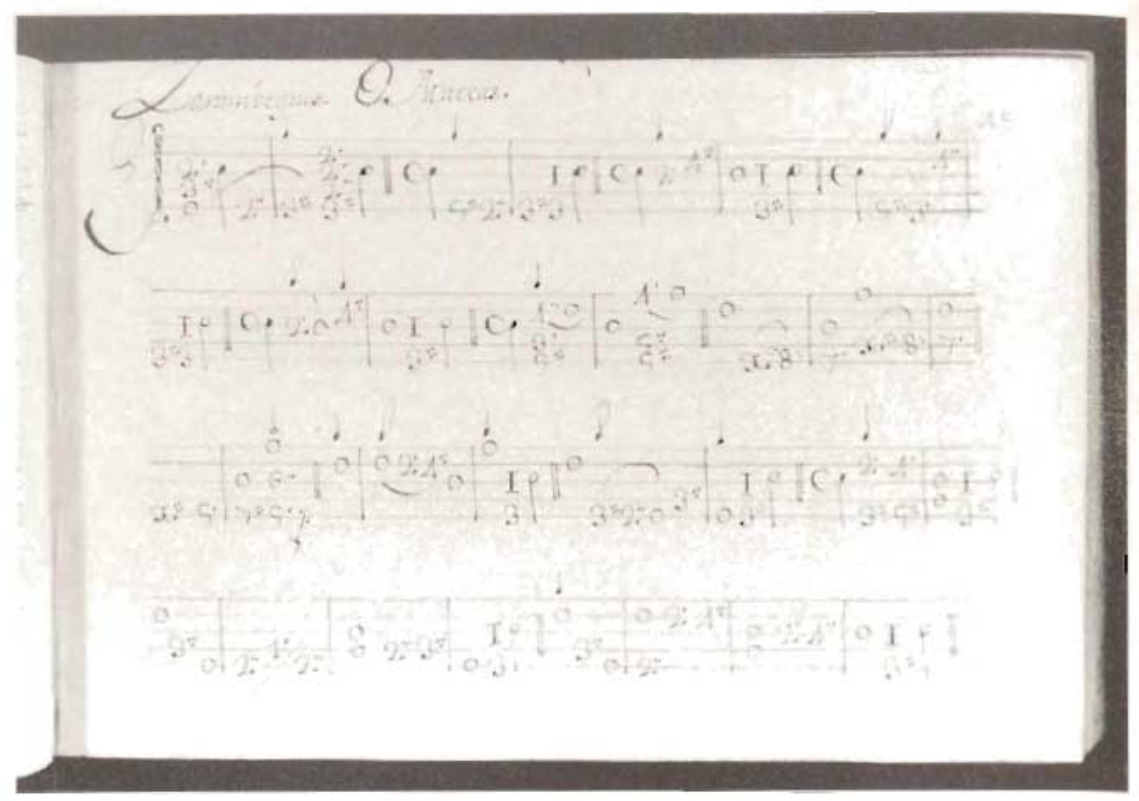

Plate 20a Códice Salvidar No. 4, fol. 45r, "Zarambeques"

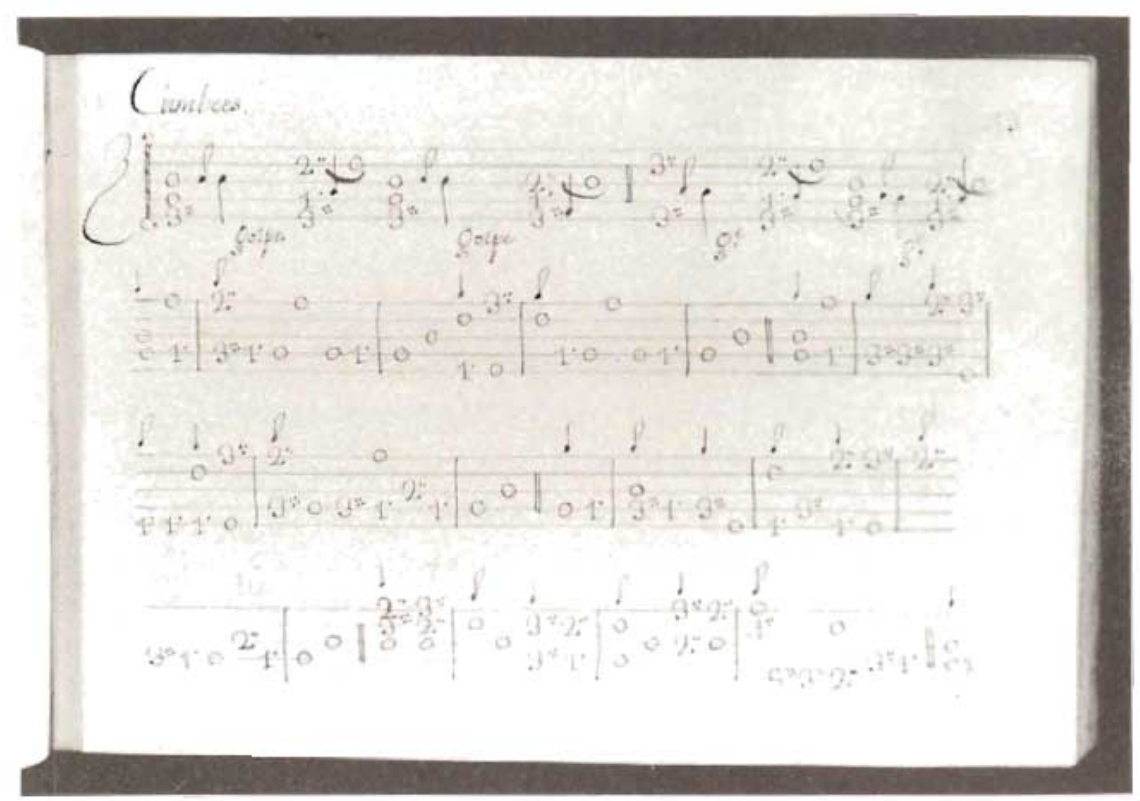

Plate 20b Códice Salvidar No. 4, fol. 43r, "Cumbées"

1960s, and with the musical revolutions of jazz, blues, rock, and heavy metal in the late twentieth century - was already playing the role of revolutionary from its early history back in the 1600s and 1700 s. In both eras, it was at the forefront of change. Today, we find that subversive yet noble instrument in 
the hands of tuxedoed classical guitarists (such as David Tanenbaum and Bill Kanengiser, playing Brouwer, Britten, and Henze), while at the same time we find it played by kids in baggy pants hunkering down to let loose a wild blues riff, rocking rhythm, or heavy-metal solo. Really, it is not as far a step from B. B. King to Murcia's "Cumbées" as we might first suspect. If we look carefully, the daring steps taken by a Hendrix or Satriani are foreshadowed in many ways by the bold and pioneering steps taken by a Montesardo or Corbetta. History has shown the guitar's ability to anticipate (or adapt to) musical and stylistic changes long before most other instruments. Rarely has the world seen an instrument more beloved, more versatile, or more attuned to the twists and turns of our ephemeral society and unpredictable history than the revolutionary, rambunctious, and radical guitar. 